\title{
Emergence of Conilon Coffee Seedlings Originating from Seeds Treated with a Sodium Hypochlorite Solution
}

\author{
Raquel Fialho Rubim ${ }^{*}$, Henrique Duarte Vieira1, Eduardo Fontes Araújo², \\ Anna Christina Sanazário de Oliveira ${ }^{1}$, Alexandre Pio Viana ${ }^{1}$ \\ ${ }^{1}$ Center of Agricultural Sciences and Technologies, State University of North Fluminense Darcy Ribeiro, \\ Campos dos Goytacazes, Brazil \\ ${ }^{2}$ Department of Plant Science, Federal University of Viçosa, Viçosa, Brazil \\ Email: ${ }^{*}$ raquel rubim@yahoo.com.br
}

Received 25 March 2014; revised 24 April 2014; accepted 10 May 2014

Copyright (C) 2014 by authors and Scientific Research Publishing Inc. This work is licensed under the Creative Commons Attribution International License (CC BY). http://creativecommons.org/licenses/by/4.0/

(c) (i) Open Access

\section{Abstract}

The coffee seeds are problematic for the physiologycal quality, featuring low speed of seedling emergence. In this sense, this work was developed with the objective of evaluating the effect of sodium hypochlorite in the removal of the parchment and in the emergence and seedlings development of conilon coffee in nursery conditions. Coffee seeds of the variety Victoria were used, which were harvested in the cherry stage and pulped by hand. Seeds were dried in an oven with forced ventilation until reaching moisture contents of $35 \%, 30 \%$ and $25 \%$ wet basis. Then, the seeds with parchment were soaked in a sodium hypochlorite solution with concentrations of $4 \%, 5 \%, 6 \%$ and 7\% active chlorine for 3 and 6 hours. For each moisture content, two additional treatments were added consisting of seeds with parchment and seeds in which the structure was removed manually. The characteristics evaluated were: emergence speed index, total emergence, dry mass of the shoots and root system. Utilization of sodium hypochlorite promoted an acceleration in seedling emergence speed similar to the method for manual removal of the parchment when using concentrations of $4 \%, 5 \%, 6 \%$ and $7 \%$ for 3 hours, at all moisture contents.

\section{Keywords}

Coffea canephora, Soaking, Seeds, Parchment

\footnotetext{
${ }^{*}$ Corresponding author.
} 


\section{Introduction}

World coffee production is distributed among many countries and the Brazil has always occupied a prominent position in this activity as a major world producer and exporter [1]. In Brazil two main species are produced on the large scale: Coffea arabica and Coffea canephora [2]. Brazilian conilon coffee (Coffea canephora) is of great importance in exportation, in industrialization as a roasted coffee and ground in blends with arabica coffee, and especially in industrialization as instant coffee.

However, seeds of this species present slow and uneven germination, in the field conditions [3]. Rapid loss of viability of these seeds together with the low rate of emergence affects planning of seedling production to meet demands at times most suitable for good plant growth [4].

Presence of the endocarp, a thin, hard and leather-like hull, known as the parchment, is one of the causes for slow germination of coffee seeds. However, the real cause of inhibition of this structure is not known. According to [5], this inhibition is not due to insufficient absorption of water, but a resistance mechanism imposed by the parchment on the developing embryo. [6] concluded that removal of the parchment successfully accelerated the emergence of seedlings in nursery conditions. The removal of this structure must be performed with care to avoid damaging the embryo, which is located in a very shallow layer of the seeds. Mechanical removal often causes damage to the embryo in seeds of conilon coffee [7]. However, manual removal, although highly efficient, is a laborious procedure, especially when handling large quantities of seed since the parchments are removed individually.

Thus, the development of an efficient, practical and inexpensive technique that can remove the parchment would be of great benefit to growers and nursery operators. [8] concluded that immersion of arabica coffee seeds with moisture content of $28.14 \%$ in $5 \%$ sodium hypochlorite for 6 hours, effectively degraded the parchment without harming the embryo. [9] showed that seedlings grown from seeds of arabica coffee with moisture contents of $23 \%, 28 \%$ and $33 \%$, subjected to a sodium hypochlorite solution at concentration of $4 \%$ for 3 hours showed similar emergence speeds to those that were obtained by manual removal of the parchment.

Work performed by [7] showed that soaking seeds conilon, with moisture content of $25 \%, 30 \%$ and $35 \%$, in sodium hypochlorite at concentration of $6 \%$ for 3 hours was effective in degradation of parchment, providing ideal laboratory conditions, similar germination manual removal of the parchment. Thus, it is extremely interesting to investigate the influence of sodium hypochlorite on seedling emergence of conilon coffee, since there is a lack of information for this species.

Based on these facts, the objective of the present study was to evaluate combinations of sodium hypochlorite concentrations and immersion times on removing the parchment and in accelerating the emergence and development of conilon coffee plants in nursery conditions.

\section{Materials and Methods}

The experiments were performed used conilon coffee seeds, Victoria variety, obtained from fruits harvested in the cherry stage. For extraction of the seeds, the fruits were pulped manually. Then the seeds were dried in an oven with forced ventilation at $36^{\circ} \mathrm{C}$ until reaching moisture contents of $35 \%, 30 \%$ and $25 \%$ wet basis.

To check the degradation of parchment, 250 seeds were imbibed with this structure in $125 \mathrm{~mL}$ of aqueous solution of sodium hypochlorite at concentrations of $4 \%, 5 \%, 6 \%$, and $7 \%$ of active chlorine for periods of 3 and 6 hours. For this, the seeds were placed in germination boxes using the screens of these boxes for all seeds remained immersed in the solution. The germination boxes were capped and kept in a BOD chamber at a constant temperature of $25^{\circ} \mathrm{C}$ in the dark, where they remained for the periods for each treatment [10]. Then the seeds were washed in running water. Were added for each moisture content, two additional treatments consisting of intact seeds and seeds without parchment scroll manually removed.

After applying the different treatments, the seeds were taken to a greenhouse and planted directly in perforated polyethylene bags measuring $10 \times 20 \mathrm{~cm}$, containing the Plantmax substrate and placing one seed at a depth of $2 \mathrm{~cm}$ in each bag. The bags were then covered with a layer of dry grass clippings to maintain moisture in the substrate, to prevent that the impact of irrigation water remove the substrate from the seeds and hinder the development of weeds. Irrigation was performed daily.

Effects of the treatments were evaluated by the following characteristics:

\subsection{Emergence Speed Index (ESI)}

Counting of emerged seedlings was carried out at five day intervals from emergence of the first seedling to de- 
velopment of the cotyledons. Was used for calculation the formula proposed by [11]:

$$
E S I=E_{1} / N_{1}+E_{2} / N_{2}+\cdots+E_{n} / N_{n}
$$

where:

ESI: emergence speed index;

$E_{1}, E_{2}, E_{\mathrm{n}}$ : number of seedlings in the first, second and nth evaluation;

$N_{1}, N_{2}, N_{\mathrm{n}}$ : number of elapsed days from sowing to first, second and nth evaluation.

\subsection{Total Emergence}

The percentage of total seedling emergence was determined by counting the number of normal seedlings emerged in the last assessment of the ESI.

\subsection{Dry Mass of the Shoot and Root Systems}

Upon completing the emergence test, the seedlings were removed from the substrate, washed and the shoots and roots were separated and placed in paper bags for drying during 72 hours in an oven at $70^{\circ} \mathrm{C}$ with forced air circulation. Weighing was performed on a precision scale before and after drying, where the results are expressed in milligrams per plant (mg.plant ${ }^{-1}$ ).

\subsection{Statistical Analysis}

A randomized block experimental design was adopted with four repetitions in a $3 \times 4 \times 2+6$ factorial, i.e., three degrees of initial moisture content, four concentrations of sodium hypochlorite, two immersion times and six additional treatments (intact seeds with parchment and seeds in which the parchment was removed manually for each moisture content). The experimental data were subjected to analysis of variance. For quantitative variables regression analysis was performed. For each moisture content, the treatments obtained from the combinations of sodium hypochlorite concentrations and pre-soaking times were compared to additional treatments applying the Tukey test at 5\% probability, since the comparison of joint and other additional treatments.

\section{Results and Discussion}

Because there was no significant difference between the different moisture contents for additional treatments at levels of $1 \%$ and $5 \%$ probability, in all additional trials for all characteristics evaluated the mean of the observed variables was used in the three initial moisture contents.

Considering the period of exposure of coffee seeds in a solution of sodium hypochlorite for 3 hours, there was no significant difference for the rate of speed of seedling emergence in all degrees of moisture and concentrations tested, thus, using the average this variable (Figures 1(A)-1(C)).

At 6 hours, for all humidities, there was a decrease in the speed index seedling emergence as the concentration of sodium hypochlorite increased (Figures 1(A)-1(C)). It is noted that in the treatment with $35 \%$ humidity and concentration of 7\%, this ratio was zero, which can also be seen from Table 1, with lethal to the seed. Higher concentration of sodium hypochlorite for 6 hours essential structures may be damaged seeds such as the embryo, since it is located in the surface layer thereof.

In Table 1, it was observed that for all moisture contents the treatments with sodium hypochlorite concentrations of $5 \%, 6 \%$ and $7 \%$ for the period of three hours did not statistically differ from the additional treatment in which the parchment was removed manually, demonstrating that sodium hypoclorite addition to efficiently degrading the parchment it did not cause damage to the embryo. In seeds with 25\%, 30\% and 35\% moisture content, the pre-germinative treatments with sodium hypochlorite at a concentration of $4 \%$ for 3 and 6 hours also resulted in emergence speeds similar to seeds in which the parchment was removed manually.

[9] showed that application of $4 \%$ sodium hypochlorite for 3 hours is as effective as manual removal of the parchment with regards to emergence speed of arabica coffee seedlings, which is in accordance with the results of this work.

Analyzing the exposure time of the seeds in the sodium hypochlorite solution for 6 hours, it was observed that the concentration of $4 \%$ was the only treatment which showed satisfactory results for all moisture contents. Furthermore, when considering the period of 6 hours it is noticed that higher concentrations (6\% and 7\%) for all 

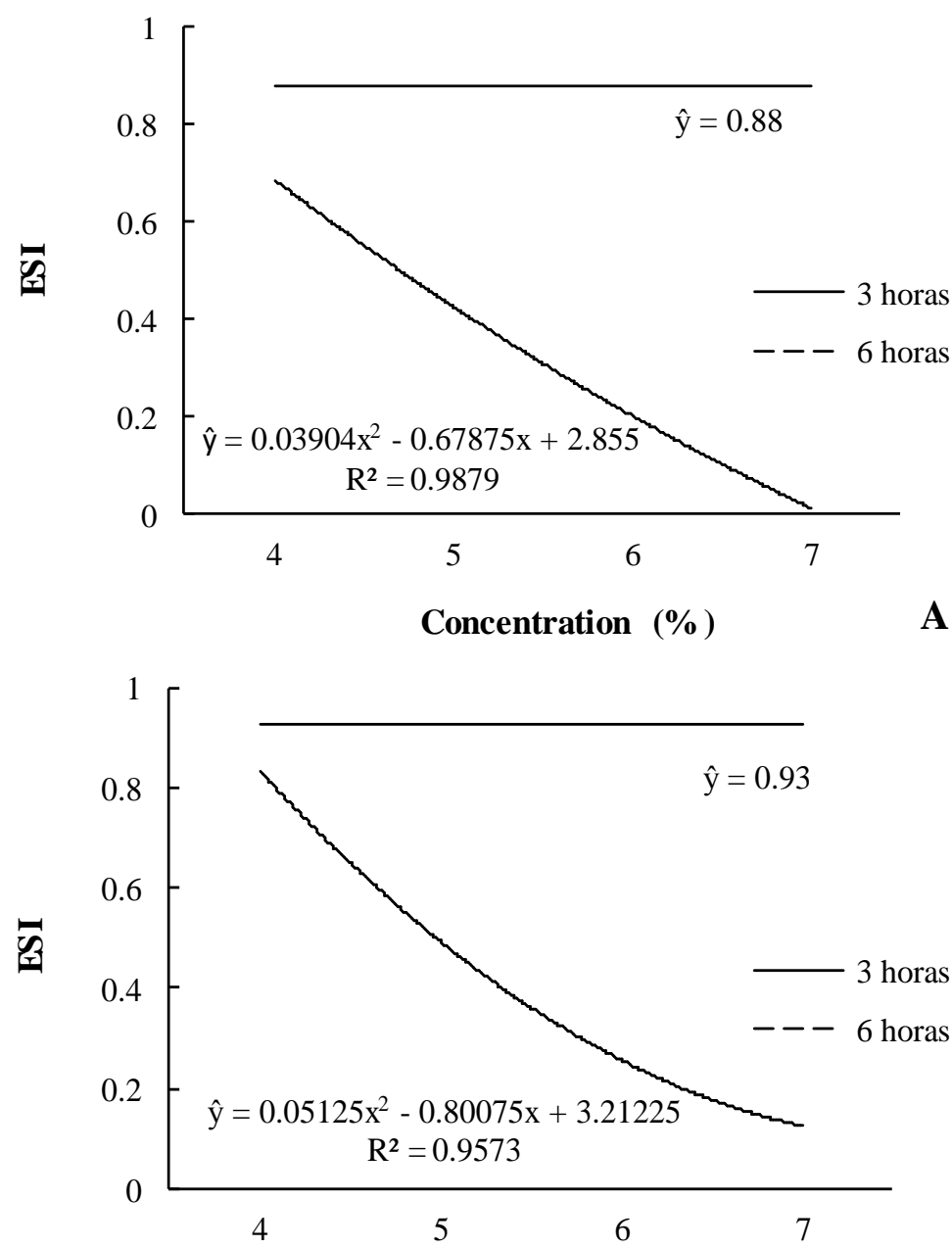

Concentration (\%)

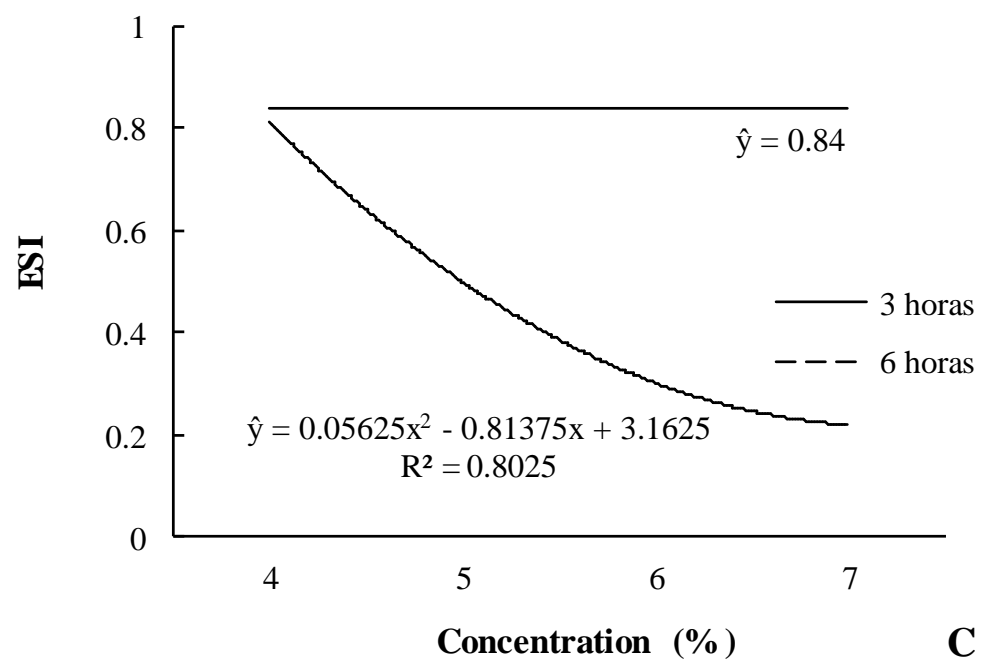

Figure 1. Emergence speed index of conilon coffee seedling from seeds with moisture content of $35 \%(\mathrm{~A})$; $30 \%$ (B) and $25 \%$ (C), after treatment with sodium hypochlorite at concentrations of $4 \%, 5 \%, 6 \%$ and $7 \%$ for periods of 3 and 6 hours. 
Table 1. Emergence speed index of conilon coffee seedlings after treatment with sodium hypochlorite at the concentrations of $4 \%, 5 \%, 6 \%$ and $7 \%$ for periods of 3 and 6 hours.

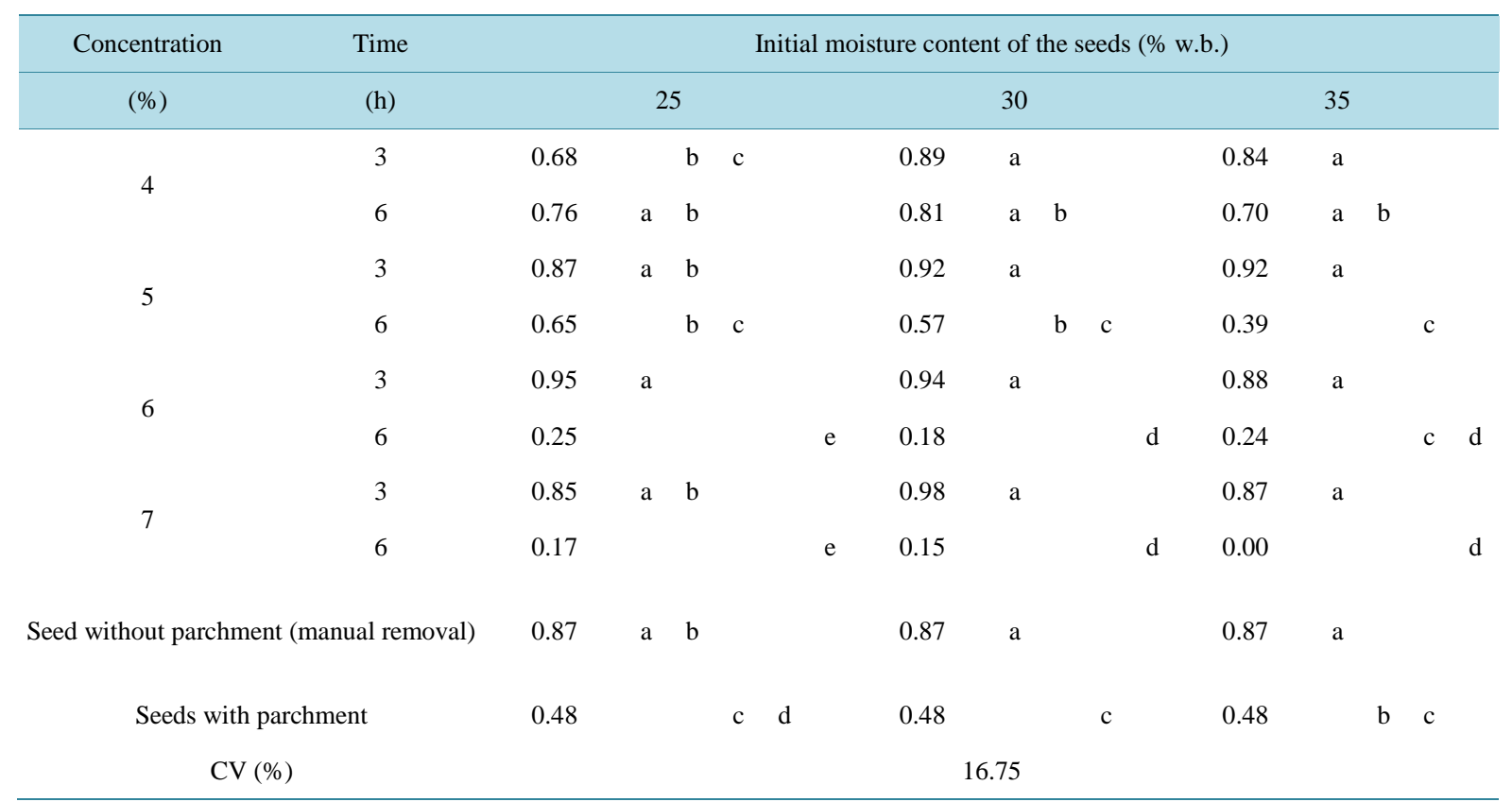

Averages followed by the same letter in the column do not differ at the level of $5 \%$ probability by the Tukey test.

moisture contents reduced the emergence speed of the plants, possibly due to damage to the embryo tissues of the seeds since sodium hypochlorite is a strong oxidant [12] and also because of increased absorption of the hypochlorite solutions at these concentrations and immersion times [10].

When comparing the seeds whose parchment was removed manually with those remaining with this structure, it is apparent that the removal promoted higher ESI. These results corroborate with those of [6], who found that manual removal of the parchment effectively accelerates the emergence of arabica coffee.

It is observed by the regressions, which in the period of exposure of the seeds in a solution of sodium hypochlorite for 3 hours, the total seedling emergence coffee increased to concentrations of $5.1 \%$ and $6.5 \%$ for moisture of $35 \%$ and $25 \%$, respectively, and thereafter decreased with increasing concentrations (Figures 2(A)-(C)). These values were obtained for the first of the regression equations derived 2nd degree. In seedlings from seeds with initial moisture of 30\%, there was no significant difference for total emergence (Figure 2(B)).

In a 6 hours period, in all moisture evaluated, seedling emergence of coffee decreased with increasing concentrations of sodium hypochlorite.

In Table 2 it appears that seeds with 25\% and 30\% moisture content, submitted to the solution of sodium hypochlorite at concentrations of $6 \%$ and $7 \%$ for 6 hours, showed lower emergence levels in comparison with other treatments. For the moisture content of 35\%, it appears that the pre-germinative treatment with sodium hypochlorite at a concentration of 7\% for 6 hours resulted in no seedling emergence. Seeds at this moisture content exposed to concentrations of $5 \%$ and $6 \%$ of sodium hypochlorite for 6 hours showed a reduction in emergence percentage in relation to the other treatments. According to [13], in certain seeds whose teguments presented no physical barrier to germination, the use of sodium hypochlorite can cause damage to the embryo tissues. [8] also found that high concentrations of sodium hypochlorite (7.5\% and 10\%) affect the germination process and reduce the final percentage of normal arabica coffee seedlings, possibly due to damage deeper in the seeds.

In Table 2, it can be seen that regardless of the initial moisture content of the seeds, the concentrations of $4 \%$, $5 \%, 6 \%$ and $7 \%$ for a period of time of 3 hours gave percentage of statistically equal to emergency treatment where additional removal parchment was performed manually.

[14] observed that immersion of arabica coffee seeds with $12 \%, 16 \%$ and $20 \%$ humidity in aqueous solution of sodium hypochlorite at concentrations of $3 \%, 4 \%$ and $5 \%$ for 3 hours, degraded parchment efficiently and accelerated seedling emergence, matching with the results found in this study.

Seeds whose parchment was manually removed reached emergence percentages greater than $90 \%$ for all 

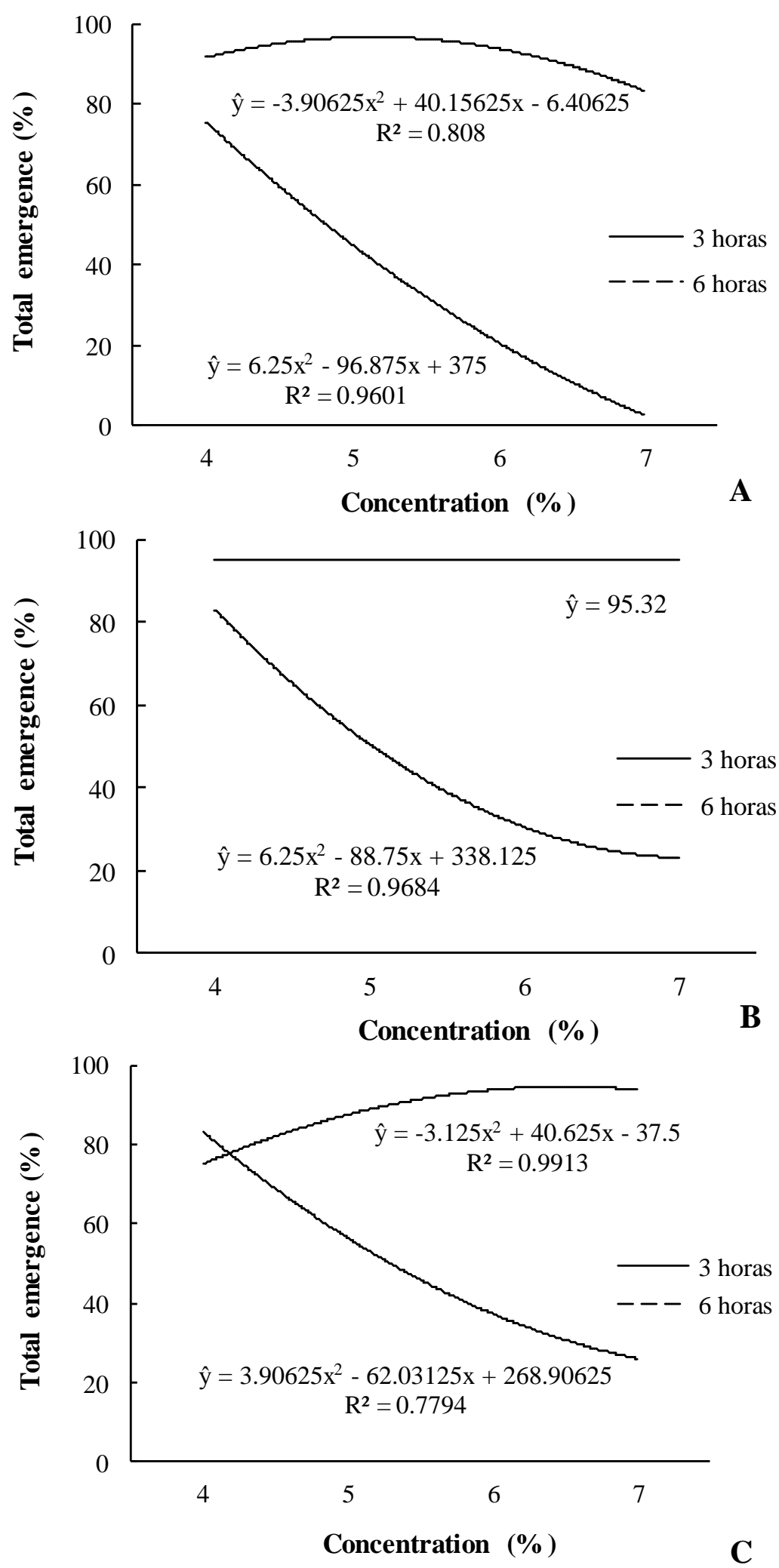

Figure 2. Total emergence of conilon coffee seedling from seeds with moisture content of $35 \%$ (A); $30 \%$ (B) and $25 \%$ (C), after treatment with sodium hypochlorite at concentrations of $4 \%, 5 \%, 6 \%$ and $7 \%$ by at 3 and 6 hours. 
Table 2. Total emergence of conilon coffee plants (\%) after treatment with sodium hypochlorite at the concentrations of $4 \%$, $5 \%, 6 \%$ and $7 \%$ for periods of 3 and 6 hours.

\begin{tabular}{|c|c|c|c|c|c|c|c|c|c|c|c|c|c|}
\hline Concentration & Time & \multicolumn{11}{|c|}{ Initial moisture content of the seeds (\% w.b.) } & \\
\hline$(\%)$ & (h) & \multicolumn{2}{|c|}{25} & & \multicolumn{4}{|c|}{30} & \multicolumn{4}{|c|}{35} & \\
\hline \multirow{2}{*}{4} & 3 & 75.0 & $\mathrm{a}$ & & 96.9 & $\mathrm{a}$ & $\mathrm{b}$ & & 90.6 & a & $\mathrm{b}$ & & \\
\hline & 6 & 78.1 & $\mathrm{a}$ & & 81.3 & $\mathrm{a}$ & $\mathrm{b}$ & c & 78.1 & a & $\mathrm{b}$ & & \\
\hline \multirow{2}{*}{5} & 3 & 87.5 & $\mathrm{a}$ & & 100.0 & $\mathrm{a}$ & & & 100.0 & a & & & \\
\hline & 6 & 71.9 & $\mathrm{a}$ & & 56.3 & & & c & 37.5 & & & c & \\
\hline \multirow{2}{*}{6} & 3 & 93.8 & $\mathrm{a}$ & & 90.6 & $\mathrm{a}$ & $\mathrm{b}$ & & 90.6 & $\mathrm{a}$ & $\mathrm{b}$ & & \\
\hline & 6 & 21.9 & & $\mathrm{~b}$ & 25.0 & & & & 28.1 & & & c & \\
\hline \multirow{2}{*}{7} & 3 & 93.8 & $\mathrm{a}$ & & 93.8 & a & $\mathrm{b}$ & & 84.4 & a & $\mathrm{b}$ & & \\
\hline & 6 & 31.3 & & $\mathrm{~b}$ & 25.0 & & & & 0.0 & & & & $\mathrm{~d}$ \\
\hline \multicolumn{2}{|c|}{ Seed without parchment (manual removal) } & 92.7 & a & & 92.7 & a & $\mathrm{b}$ & & 92.7 & a & $\mathrm{b}$ & & \\
\hline \multicolumn{2}{|c|}{ Seeds with parchment } & 70.8 & a & & 70.8 & & $\mathrm{~b}$ & c & 70.8 & & $\mathrm{~b}$ & & \\
\hline \multicolumn{2}{|c|}{ CV (\%) } & \multicolumn{11}{|c|}{16.25} & \\
\hline
\end{tabular}

Averages followed by the same letter in the column do not differ at the level of $5 \%$ probability by the Tukey test.

moisture contents. [15] reported that manual removal of the parchment from arabica coffee seeds resulted in greater emergence speed and accelerated the formation of seedlings.

In the period of exposition in a solution of sodium hypochlorite for 3 hours, there was no significant effect of different concentrations for the dry mass of the aerial part of the variable coffee plantlets in all moisture contents (Figures 3(A)-(C)). This also occurred in seedlings from seeds with initial moisture content of $30 \%$ for 6 hours immersed in a solution of sodium hypochlorite (Figure 3(B)).

In a 6 hours period, a reduction of the dry mass of the aerial part of seedlings of coffee as the concentration of sodium hypochlorite increased humidity of 35\% (Figure 3(A)). In seedlings originated from seeds with 25\%, it was noticed that there was an increase in the dry mass of the aerial part to the concentration of $4.7 \%$, followed by a decrease thereafter (Figure 3(C)).

The dry mass of the shoots of conilon coffee seedlings did not differ statistically between treatments when seeds presented 30\% moisture content. In seedlings originated from seeds with $35 \%$ and $25 \%$ moisture, the treatment with 7\% sodium hypochlorite for a period of 6 hours was the only treatment that caused a significant reduction of the dry mass of the shoots of seedlings in relation to the removal parchment manual, and there was no moisture in the first seedling emergence (Table 3).

In a 3 hours period soaking seeds in a solution of sodium hypochlorite, dry root weight of seedlings of coffee was not significantly affected in moisture of 35\% and 30\% (Figure 4(A) and Figure 4(B)). Seedlings from seeds with $25 \%$ moisture showed an increase in dry mass of the root system to the concentration of $5.8 \%$. From this concentration, it occured the same decrease (Figure 4(C)).

Analyzing 6 hours period, there was an increase in dry root weight of seedlings to $4.9 \%$ concentration of sodium hypochlorite in the moisture of $35 \%$. From this value decreased slightly as the concentration increased. For other moisture, there was no significant effect of concentration for this variable.

Dry weight of the root system in coffee seedlings showed a similar behavior to the dry mass of shoots for the three humidities, i.e., at 30\% moisture there was no difference between treatments and for $35 \%$ the same was observed, except for the concentration of 7\% during 6 hours, since there was no emergence of seedlings. In seeds with $25 \%$ moisture content, the pre-germination treatment with sodium hypochlorite at a concentration of $7 \%$ for 6 hours was the only treatment with weight lower than that in which the parchment was removed manually (Table 4).

Evaluation of the dry masses of the shoots and root systems indicate that the use of sodium hypochlorite not 

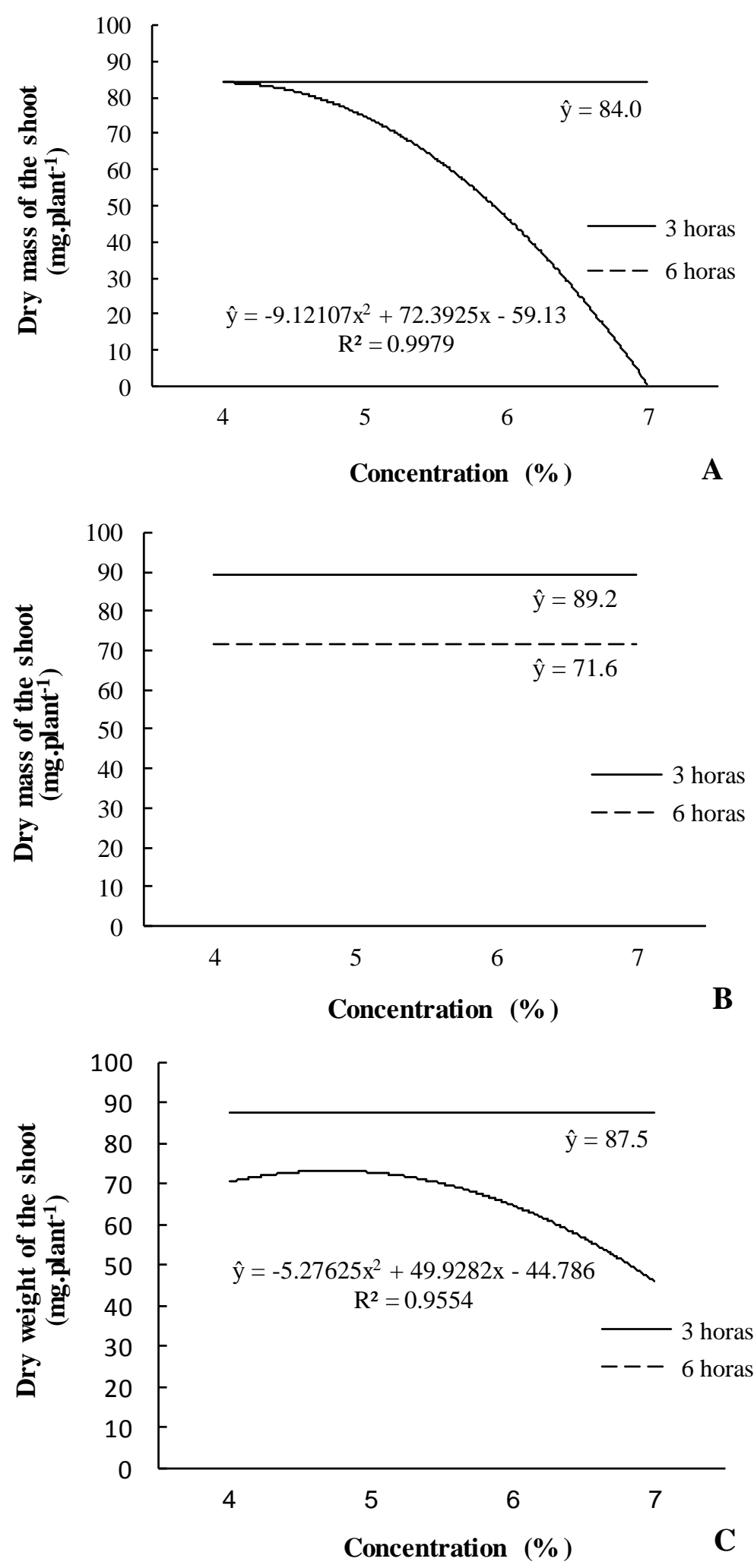

Figure 3. Dry mass of the shoots of the conilon coffee seedling from seeds with moisture content of 35\% (A); 30\% (B) and 25\% (C), after treatment with sodium hypochlorite at concentrations of $4 \%, 5 \%, 6 \%$ and $7 \%$ for periods of 3 to 6 hours. 
Table 3. Dry mass of the shoots of the conilon coffee seedling $\left(\mathrm{mg} \cdot\right.$ plant $\left.^{-1}\right)$ after treatment with sodium hypochlorite at the concentrations of $4 \%, 5 \%, 6 \%$ and $7 \%$ for periods of 3 and 6 hours.

\begin{tabular}{|c|c|c|c|c|c|c|c|c|c|}
\hline Concentration & Time & \multicolumn{7}{|c|}{ Initial moisture content of the seeds (\% w.b.) } & \\
\hline (\%) & (h) & \multicolumn{2}{|c|}{25} & & \multicolumn{2}{|c|}{30} & \multicolumn{3}{|c|}{35} \\
\hline \multirow{2}{*}{4} & 3 & 83.9 & a & $\mathrm{b}$ & 82.8 & a & 87.4 & a & \\
\hline & 6 & 69.5 & a & $\mathrm{b}$ & 72.5 & a & 84.7 & a & \\
\hline \multirow{2}{*}{5} & 3 & 86.2 & a & $\mathrm{b}$ & 89.4 & a & 87.0 & $\mathrm{a}$ & \\
\hline & 6 & 76.0 & a & $\mathrm{b}$ & 62.9 & a & 72.8 & a & \\
\hline \multirow{2}{*}{6} & 3 & 89.4 & $\mathrm{a}$ & $\mathrm{b}$ & 90.1 & a & 81.2 & a & \\
\hline & 6 & 61.8 & a & $\mathrm{b}$ & 72.8 & a & 48.9 & $\mathrm{a}$ & \\
\hline \multirow{2}{*}{7} & 3 & 90.6 & a & $\mathrm{b}$ & 94.7 & a & 80.5 & $\mathrm{a}$ & \\
\hline & 6 & 47.2 & & $\mathrm{~b}$ & 78.1 & a & 0.0 & & $\mathrm{~b}$ \\
\hline \multicolumn{2}{|c|}{ Seed without parchment (manual removal) } & 91.5 & a & & 91.5 & $\mathrm{a}$ & 91.5 & $\mathrm{a}$ & \\
\hline \multicolumn{2}{|c|}{ Seeds with parchment } & 73.5 & a & $\mathrm{b}$ & 73.5 & $\mathrm{a}$ & 73.5 & a & \\
\hline \multicolumn{2}{|c|}{ CV (\%) } & \multicolumn{8}{|c|}{24.48} \\
\hline
\end{tabular}

Averages followed by the same letter in the column do not differ at the level of 5\% probability by the Tukey test.

Table 4. Dry mass of the root system of the conilon coffee seedling $\left(\mathrm{mg} \cdot\right.$ plant $\left.^{-1}\right)$ after treatment with sodium hypochlorite at the concentrations of $4 \%, 5 \%, 6 \%$ and $7 \%$ for periods of 3 and 6 hours.

\begin{tabular}{|c|c|c|c|c|c|c|c|c|c|}
\hline \multirow{2}{*}{$\begin{array}{c}\text { Concentration } \\
(\%)\end{array}$} & \multirow{2}{*}{$\begin{array}{l}\text { Time } \\
\text { (h) }\end{array}$} & \multicolumn{8}{|c|}{ Initial moisture content of the seeds (\% w.b.) } \\
\hline & & \multicolumn{2}{|c|}{25} & & \multicolumn{2}{|c|}{30} & \multicolumn{3}{|c|}{35} \\
\hline \multirow{2}{*}{4} & 3 & 13.8 & a & $\mathrm{b}$ & 16.8 & a & 17.1 & a & $\mathrm{b}$ \\
\hline & 6 & 9.9 & a & $\mathrm{b}$ & 11.0 & a & 15.5 & a & $\mathrm{b}$ \\
\hline \multirow{2}{*}{5} & 3 & 20.6 & a & $\mathrm{b}$ & 21.2 & a & 20.9 & a & \\
\hline & 6 & 10.9 & a & $\mathrm{b}$ & 13.4 & a & 18.6 & a & \\
\hline \multirow{2}{*}{6} & 3 & 24.8 & a & & 21.2 & a & 20.6 & a & \\
\hline & 6 & 9.3 & a & $\mathrm{b}$ & 11.7 & a & 11.3 & a & $\mathrm{b}$ \\
\hline \multirow{2}{*}{7} & 3 & 18.4 & a & $\mathrm{b}$ & 26.9 & a & 19.1 & a & \\
\hline & 6 & 6.1 & & $\mathrm{~b}$ & 9.0 & $\mathrm{a}$ & 0.0 & & $\mathrm{~b}$ \\
\hline \multicolumn{2}{|c|}{ Seed without parchment (manual removal) } & 24.7 & a & & 21.7 & a & 21.7 & a & \\
\hline \multicolumn{2}{|c|}{ Seeds with parchment } & 10.1 & a & $\mathrm{b}$ & 10.1 & a & 10.1 & a & $\mathrm{b}$ \\
\hline \multicolumn{2}{|c|}{ CV (\%) } & \multicolumn{8}{|c|}{47.26} \\
\hline
\end{tabular}

Averages followed by the same letter in the column do not differ at the level of 5\% probability by the Tukey test.

only resulted in good emergence, but did not affect proper development of conilon coffee seedlings.

The use of pre-germination treatments involving partial or total immersion of the seeds has grown significantly in order to improve performance [16]. In the present study the treatment of conilon coffee beans with sodium hypochlorite showed good results, showing to be a promising technique for the degradation of parchment and acceleration of seedling emergence, as well as presenting low costs and low risk to the operator. 

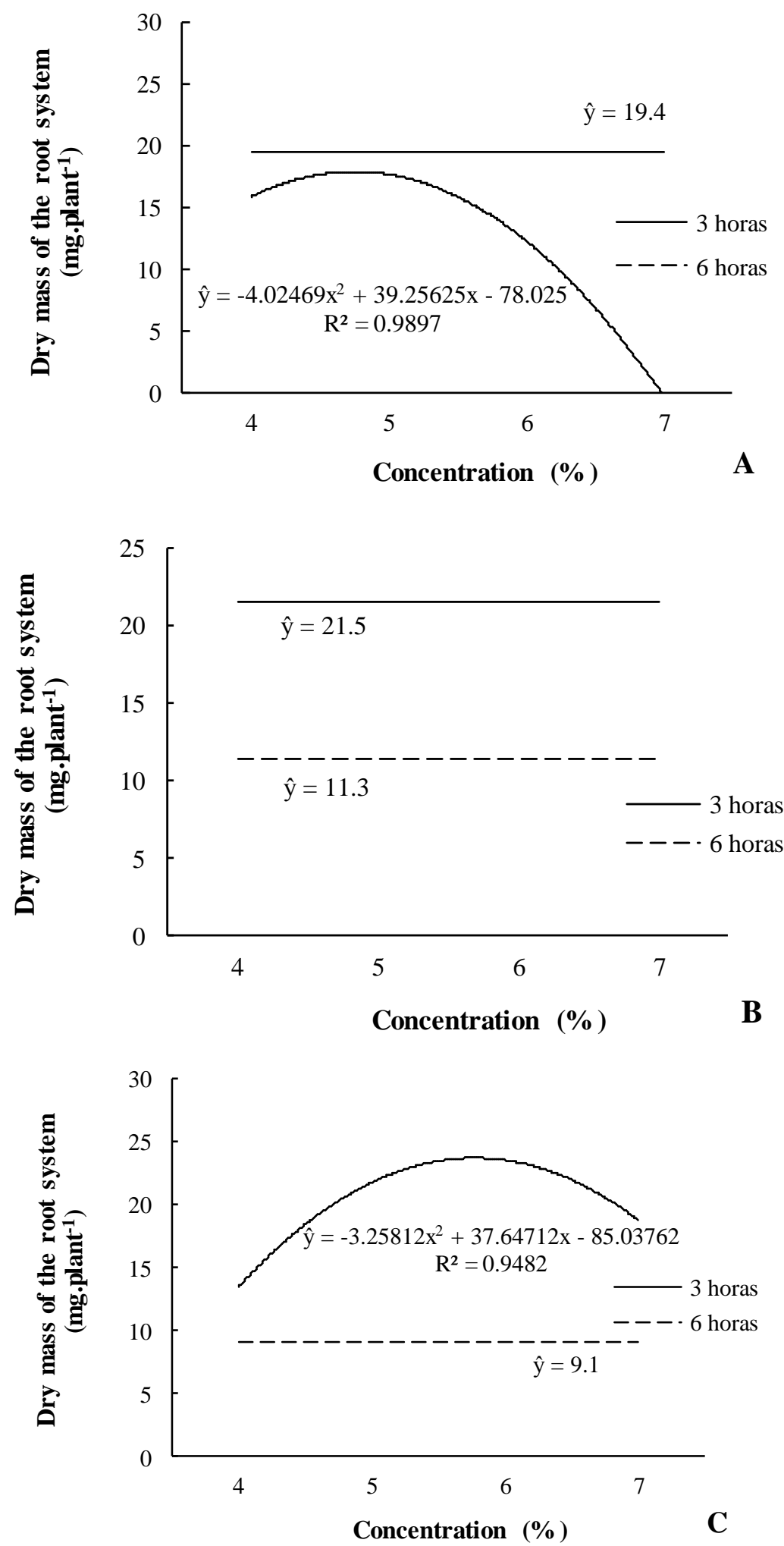

Figure 4. Dry mass of the root system of the conilon coffee seedling from seeds with moisture content of 35\% (A); 30\% (B) and 25\% (C), after treatment with sodium hypochlorite at concentrations of $4 \%, 5 \%$, and $6 \%, 7 \%$ for periods of 3 and 6 hours. 


\section{Conclusions}

The use of sodium hypochlorite at concentrations of $4 \%, 5 \%, 6 \%$ and $7 \%$ for 3 hours, regardless of initial moisture content of the seeds, has a similar effect on manual removal of the parchment with regards to emergence percentage and speed for the coffee seedlings, and shoot and root dry mass.

The immersion of conilon coffee seeds in a 7\% sodium hypochlorite solution for 6 hours reduced the emergency speed index and seedling development.

In general, the use of sodium hypochlorite in pre-germinating treatments of conilon coffee seeds showed a promising technique of low cost.

\section{Acknowledgements}

To the UENF for the scholarship; and to the CNPq and FAPEMIG for their financial support.

\section{References}

[1] Freire, A.H., Reis, R.P., Veiga, R.D. and Fontes, R.E. (2011) Economic Efficiency of Coffee in the South of Minas Gerais: One Application of Production Frontier. Coffee Science, 6, 172-183. http://www.coffeescience.ufla.br/index.php/Coffeescience/article/view/310

[2] Matiello, J.B., Santinato, R., Garcia, A.W.R., Almeida, S.R. and Fernandes, D.R. (2005) Coffee Culture in Brazil: New Recommendations Manual. MAPA: SARC/PROCAFÉ—SPAE/DECAF.

[3] Fagundes, A.V., Rosa, S.D.V.F. and Ribeiro, F.L.F. (2009) Accelerated Training of Seedlings of Coffea arabica L., cv “Topázio" According with the Withdrawal of Parchment. Brazilian Journal of Storage, 11, 1-6.

[4] Fonseca, S.C.L. and Freire, H.B. (2003) Recalcitrants Seeds: Post-Harvest Problems. Bragantia, 62, 297-303. http://www.scielo.br/pdf/brag/v62n2/v62n2a16.pdf http://dx.doi.org/10.1590/S0006-87052003000200016

[5] Valio, I.F.M. (1980) Inhibition of Germination of Coffee Seeds (Coffea Arabica L. cv. Mundo Novo) by the Endocarp. Journal of Seed Technology, 5, 32-39.

[6] Araújo, E.F., Reis, L.S., Meireles, R.C. and Serrano, L.A.L. (2004) Effect of Mechanical Damage and Manual Removal of the Parchment on the Emergence Seedlings of Coffea arabica L. Brazilian Journal of Storage, 8, 1-5.

[7] Rubim, R.F., Vieira, H.D., Araújo, E.F., Viana, A.P. and Coelho, F.C. (2010) Sodium Hypochlorite Treatment to Remove the Parchment and Accelerate Germination of Conilon Coffee Seed. Journal of Seed Science, 32, 88-98. http://www.scielo.br/pdf/rbs/v32n4/10.pdf

[8] Meireles, R.C., Araújo, E.F., Reis, M.S., Sediyama, C.S., Sakiyama, N.S. and Reis, L.S. (2007) Secafé: Coffee Seeds Germination Acceleration Method. Journal of Seed Science, 29, 80-86. http://www.scielo.br/pdf/rbs/v29n3/a12v29n3.pdf

[9] Sofiatti, V., Araújo, E.F., Araújo, R.F., Cargnin, A., Reis, M.S. and Silva, L.V.B.D. (2009) Use of Sodium Hypochlorite to Hasten the Emergence and Development of Coffee Seedlings. Bragantia, 68, 233-240. http://www.scielo.br/scielo.php?script=sci_arttext\&pid=S0006-87052009000100025 http://dx.doi.org/10.1590/S0006-87052009000100025

[10] Sofiatti, V., Araújo, E.F., Araújo, R.F., Reis, M.S., Silva, L.V.B.D. and Cargnin, A. (2008) Use of Sodium Hypochlorite to Degrade the Endocarp in Coffee Seeds at Different Moisture Contents. Journal of Seed Science, 30, 150-160. http://www.scielo.br/pdf/rbs/v30n1/a19v30n1.pdf

[11] Maguire, J.D. (1962) Speed of Germination-Aid in Selection and Evoluation for Seedling Emergence and Vigor. Crop Science, 2, 176-177. http://dx.doi.org/10.2135/cropsci1962.0011183X000200020033x

[12] Viggiano, J.R., Silva, R.F. and Vieira, H.D. (2000) The Occurrence of Dormancy in Papaya Seeds (Carica papaya L.). Seeds Online, 1, 6-10.

[13] Carnelossi, M.A.G., Lamounier, L. and Ranal, M.A. (1995) Effect of Light, Sodium Hypochlorite, Scarification and Stratification on Seed Germination of Lettuce (Lactuca sativa L.) cv. Maioba and Moreninha-de-Uberlândia. Brazilian Agricultural Research, 30, 779-787. http://seer.sct.embrapa.br/index.php/pab/article/view/4362/1648

[14] Lima, J.S., Araújo, E.F., Araújo, R.F., Dias, L.A.S., Dias, D.C.F.S. and Rena, F.C. (2012) Use of Re-Hydration and Sodium Hypochlorite to Accelerate Coffee Seedlings Emergence. Journal of Seed Science, 34, 327-333. http://www.scielo.br/pdf/rbs/v34n2/19.pdf

[15] Rosa, S.D.V.F., Melo, L.Q., Veiga, A.D., Oliveira, S., Souza, C.A.S. and Aguiar, V.A. (2007) Coffea arabica L. cv. Ruby Seedlings Formation from Seeds or Berries at Different Developmental Stages. Science and Agrotechnology, 31, 349-356. http://www.scielo.br/pdf/cagro/v31n2/a13v31n2.pdf 
[16] Sguarezi, C.N., Braccini, A.L., Scapim, C.A., Braccini, M.C.L. and Dalpasquale, V.A. (2001) Evaluation of Presowing Treatments to Improve Performance on Coffee (Coffea arabica L.) Seed. II. Humidifying Process. Journal of Seed Science, 23, 162-170. http://www.abrates.org.br/revista/artigos/2001/v23n2/artigo23.pdf 